\title{
CHICKEN PRICE TRANSMISSION ELASTICITY IN SÃO PAULO STATE MARKET
}

\author{
U. CORRÊA ${ }^{1 *}$, B. P. V. B. RIBEIRO ${ }^{1}$, F. M. CARVALHO ${ }^{1}$, G. C. BENEDICTO ${ }^{1}$ and E. A. CORRÊA ${ }^{2}$, B. W. A. CORRÊA ${ }^{3}$ \\ ${ }^{1}$ Universidade Federal de Lavras, ${ }^{2}$ Universidade Federal de Minas Gerais \\ ${ }^{3}$ Instituto Federal de Minas Gerais - Campus Bambuí \\ uellington.correa@gmail.com*
}

Received 05/05/2016 - Accepted 03/12/2017

DOI: $10.15628 /$ holos. 2017.4528

\section{ABSTRACT}

After implementation of the Real Plan in July 1994 by the Brazilian government, the industrial chicken was established in consumer preference causing change in their spending habits. This change was attributed in great part due to their affordability to the consumer. This article aims to analyze the price transmission elasticity of chicken in the state of São Paulo market and identify which market level focuses on the greatest power of pricing, either at the producer level, wholesale and retail. By studying São Paulo's chicken market, we intend to provide information to support decision
\end{abstract}

making by managers of the production chain. Furthermore, São Paulo is the largest chicken consumer market in the country. Therefore, it is used in the treatment of chicken price data at the producer level, wholesale and retail the econometric model of Vector Autoregressive (VAR). The results found by analyzing the variance decomposition of forecast errors demonstrate that the producer has a high power setting of prices of chicken in the São Paulo's market, having direct influence on the formation of prices both at wholesale as well as retail.

KEYWORDS: Chicken, prices, vector autoregressive model.

\section{ELASTICIDADE DE TRANSMISSÃO DE PREÇOS DA CARNE DE FRANGO NO MERCADO DO ESTADO DE SÃO PAULO}

\section{RESUMO}

Após a implantação do Plano Real, em julho de 1994, pelo governo brasileiro, o frango industrial estabeleceuse na preferência dos consumidores provocando mudança em seus hábitos de consumo. Esta mudança foi atribuída em grande parte devido os seus preços estarem acessíveis ao consumidor. O presente artigo tem por objetivo analisar a elasticidade de transmissão de preços da carne de frango no mercado do estado de São Paulo e identificar em qual nível de mercado concentra-se o maior poder de formação de preços, seja ao nível do produtor, atacado e varejo. Ao estudar o mercado de carne de frango de São Paulo, pretende-se gerar informações que subsidiem a tomada de decisões pelos gestores da cadeia produtiva no estado. Acrescenta-se que em São Paulo está concentrado o maior mercado consumidor de carne de frango do país. Para tanto é empregado no tratamento dos dados de preços da carne de frango ao nível do produtor, atacado e varejo o modelo econométrico de Vetor Autoregressivo (VAR). Os resultados encontrados por meio da análise da decomposição da variância dos erros de previsão demonstram que o produtor possui alto poder de formação dos preços da carne de frango no mercado de São Paulo, tendo influência direta na formação dos preços praticados tanto em nível de atacado como de varejo.

PALAVRAS-CHAVE: Frango, preços, modelo vetorial auto-regressivo. 


\section{INTRODUCTION}

After implementation of the Real Plan in July 1994 by the Brazilian government, the industrial chicken was established in consumer preference causing change in their spending habits. This change was attributed in great part due to their affordability to the consumer. Chicken demand was enhanced in consequence of better prices in comparison to other types of meat and to the fact that Chicken is considered healthier in relation to read meat. The fact that the production cycle is shorter with approximately 40 days until slaughter, favors large-scale production.

In additions the increase in income achieved by Brasilians over the last two decades which contributed significantly to the higher demand of chicken meat. The average monthly income of the population increased from $R \$ 689.31$ in 1995 to $R \$ 961.65$ in 2012, increasing the purchasing power of the population (Applied Economic Research Institute-IPEA, 2014).

Per capita consumption of chicken fluctuated over the past few years, jumping from 33.81 $\mathrm{kg}$ in 2002 to $35.48 \mathrm{~kg}$ in 2005, and in 2011 peaked with $47.38 \mathrm{~kg}$ retreating in 2013 to $41.80 \mathrm{~kg}$ (Brazilian Poultry Union-UBA, 2014).

Brazil currently ranks 3rd in the world ranking of poultry production after the United States and China whom are the major producers, with 16.98 (million ton.), and 13.50 (million ton.), respectively. Domestic production, in 2013, reached 12.30 (million ton.), with a domestic availability of $68.4 \%$ of the production, the largest productivity was concentrated in the state of Paraná, accounting for 31.12 \%, followed by Santa Catarina with $16.66 \%$, Rio Grande do Sul, $14.56 \%$ and São Paulo, 10.99\% (UBA, 2014).

Over the past years the poultry industry and its producers have made investments both in the breeding of birds as on the technology used in its creation. These investments were due to the high level of changes in the market and aimed at meeting the requirements to the production level demanded by the industrial and consumer segments.

The demand for higher quality of meat and the most efficient forms of production contemplated significant economic results along the chicken production chain, the logistics was perfected optimizing the distribution from the producers to the consumers.

To analyze the poultry agro-industrial chain is of paramount importance to understand the relationships between its members. The more appropriate the coordination between the chain components the fastest the adaptation changes of the market environment, considering the different economic aspects that influences the volume of supply and demand of agroindustrial products.

The agro-industrial products are basic needs and present relatively low value, a variation in their prices does not affects intensely the amount consumed, even with a rise in prices consumers hardly stop buying, consumption could be inhibited (Batalha, 2012).

Fluctuations in the prices of chicken meat are frequent due to the seasonality of production and due to the high prices of inputs used in poultry feed. However, with increasing income of the population over the last few years, followed by an increase in per capita consumption the production was favored to supply the market. 
And as the analysis of prices is a major instrument influencing the planning of agricultural production (Arêdes et al., 2009), this article aims to analyze the elasticity of price transmission from chicken in São Paulo State market and identify which market level focuses on the greatest power of pricing: the producer, wholesale or retail.

By studying the São Paulo chicken market, one intends to generate information to support decision making by managers of this production chain in the state. São Paulo is the largest chicken consumer market in the country. Therefore, the econometric model of Vector Autoregressive (VAR) is used in the treatment of chicken price data at producer, wholesale and retail levels.

This research tries to follow the same methodological strictness employed in similar studies which used the VAR model to find the results. The works of Barros (1990), Margarido, Turolla and Fernandes (2001), Weydmann and Seabra (2006), Mayorga (2007), Belk, Orth and Setzer (2010), Hassouneh, Serra and Gil (2010), Cavalcanti (2010), Fernandes et al. (2010), Viana et al. (2010), Figueiredo (2010), Wolf and Neto (2011), and Hassouneh et al. (2012) have studied the price transmission elasticity between different market levels.

Besides this introduction, the article is structured according to the following sequence: first, we present the material and methods, which discusses the database search, for the unit root tests and Johansen's cointegration tests and the VAR econometric model. Then the results are presented followed by final considerations.

\section{MATERIAL AND METHODS}

In the construction of the statistical model of this research secondary data were used to analyze the elasticity of price transmission of chicken meat in the São Paulo market at the producer level, wholesale and retail, thus the research approach is characterized as quantitative.

Quantitative studies generally seek to follow with methodological rigor a previously established plan, based on variables that are object of operational definition (Bryman, 2006; Bryman, 2007; Bryman; Becker; Sempik, 2008; Creswell, 2013). Quantitative research seeks objectivity, where the results are quantified.

Regarding the research objectives, this is classified as descriptive and explanatory, and the procedures classify as documentary. The descriptive research aims to describe the characteristics of a given phenomenon and the Explanatory research aims to identify the factors that contribute to the occurrence of events. Regarding the documentary research, this is developed from materials that have not yet received analytical treatment (Lunde; Heggen; Strand, 2012; Silva; Menezes, 2005).

\subsection{Data base}

The monthly series of chicken prices studied in this research were collected from the database of the Paulista Poultry Association (APA) and refer to the average prices in R\$/kg (Reais per kilogram) of live poultry paid to the producer, slaughtered at wholesale and made available to the end consumer. 
The review period included prices traded between the months of January 1999 to March 2014, totaling 183 observations in each market level. The behavior of prices over the period studied is shown in Figure 1.

The transfer of product prices within the same market as the market for chicken meat in the producer level, wholesale and retail in the state of São Paulo is characterized as a study of vertical price transmission elasticity.

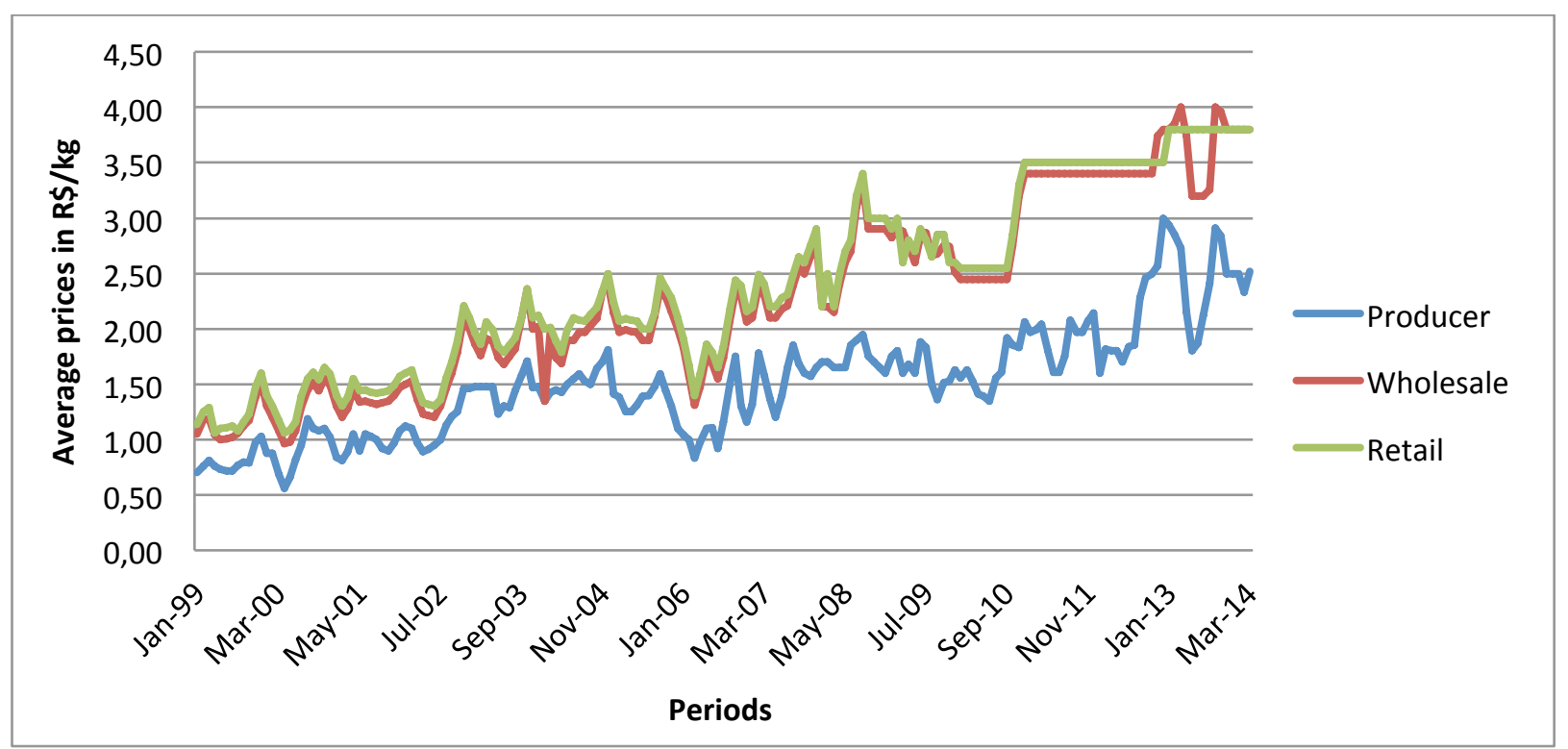

Figure 1. Average prices series kilo of chicken sold in the São Paulo's market between January 1999 to March 2014. Source: Paulista Poultry Association (2016).

Along the lines described by Margarido, Turolla and Fernandes (2001), the price transmission elasticity is "the relative change in price to a market level in relation to changes in the price to another level, kept in balance after these two market levels undergo an initial shock in one of them".

Following the guidance of the above authors regarding the analysis of the elasticity of price transmission, the price series were transformed into logarithmic basis for purposes of economic interpretation of the results. And, in the treatment of statistical data Software Gretl Gnu Regression, Econometrics and Time-series Library, version 1.9.12 was used (Adkins, 2012).

The variables or monthly series studied in the analysis of elasticity of price transmission of chicken meat in the São Paulo market refer to the live poultry, chicken slaughtered wholesale and retail, and include: I APP Producer (logarithm of the average price of live poultry to the producer), I APC Wholesale (logarithm of average price of chicken slaughtered wholesale), I APC Retail (logarithm of average price of chicken to the retail).

\subsection{Unit root test}

In studies of an economic nature is common for statistical series not to be stationary, since the prices are subject to influences of many factors, for example, prices of products of agricultural origin that have dependence on climatic factors, with certain times when there is an excess or shortage of supply, as well causing the distribution of irregular shape of the products throughout the year, may cause elevation or contraction of their prices. Thus, it becomes 
necessary to calculate the unit root test to see if the time series are stationary in level or become stationary in differences.

To identify the econometric model that best fits the time series and verify the stationarity price of chicken in the São Paulo market the unit root test of Dickey and Fuller (1979) was held. Wolf and Neto (2011) stated that the ADF test is used to check the order of integration of a time series $Y_{t}$. Figueiredo et al. (2010) believes that a $P$ series is stationary when the change originated in the time of $\mathrm{P}_{t}$ to $\mathrm{P}_{t}+\mathrm{m}$, the mean, variance and autocovariances $\mathrm{P}_{\mathrm{t}}+\mathrm{m}$ are equal to $\mathrm{P}_{\mathrm{t}}$.

According to Fernandes et al. (2010) the ADF test is calculated in price transmission elasticity studies using ordinary least squares (OLS), according to Equation (1):

$$
\Delta Y_{t}=\beta+\delta T+\gamma Y_{t-1}+\sum_{=1}^{m} \lambda_{1} \Delta Y_{t-1}+\varepsilon_{t}
$$

Where: $\beta$ is a constant (intercept); $\delta T$ is the tendency; $\Delta$ is the operator difference (represented by $\left.\Delta_{t}=Y_{t}-Y_{t-1}\right) ; \lambda_{i}=-\sum_{j=i+1}^{p} \rho_{j} ;$ and $\gamma=\sum_{i=1}^{p} \rho_{i}-1$.

Still to according to Fernandes et al. (2010) if a time series has to be differentiated "d" times, so that it becomes stationary, the series is integrated of order " $d$ ", I (d). If the series is integrated of order zero $(d=0)$ it will be at a stationary level. However, any series, whose order of integration is greater than or equal to $1(d \geq 1)$, will be non-stationary.

To perform the cointegration test it is necessary to determine the number of lags in the model. Thus, the lag is attributed by lower value Akaike (1976) Information Criterion (AIC), Bayesian Information Criterion (BIC) (Schwarz, 1978) and Hannan-Quinn (1979) Information Criterion (HQC). The number of lags of the proposed econometric model is of the order of 12, since the time series are monthly. And, the model adjustment was made to achieve the ideal fit.

\subsection{Johansen's cointegration test}

Johansen's cointegration test is intended to check the existence of long-term relationship between the variables, and test the existence of cointegration vectors in the econometric model (Johansen, 1988; Johansen; Juselius, 1990; Margarido; Turolla; Fernandes, 2001; Wooldrige, 2009).

Therefore, if all model variables have the same order of integration, they exhibit an equilibrium relationship of long-term in the understanding of Mayorga et al. (2007). Under this procedure a cointegration vector is estimated, and for $n$ variables there can be at most $N-1$ linearly independent cointegrating vectors. Thus, if the number of co-integrating vectors is equal to the number of variables, the VAR model at level is used, since to put all model variables in the level at VAR, the linear combination between them will produce a stationary relationship (Mayorga et al., 2007).

\subsection{Vector autoregression models (VAR)}

The econometric methodology used to achieve the proposed results in this study used the technique of Vector Autoregressive model. According to Cavalcanti (2010), it was from the classic article "Macroeconomics and Reality" by Sims (1980) that this methodology has gained prominence spreading rapidly among economists. 
For Adkins (2012), this model allows you to analyze the existing interrelationships between stationary variables from a minimum set of identification constraints from exogenous components of each variable. Cavalcanti (2010), in turn, adds that VAR enables to estimate the effect of a given shock on a variable over other variables. Mayorga et al. (2007) illustrates the Autoregressive model in matrix form as in Equation (2):

$$
Y_{t}=\alpha+\Pi_{1} Y_{t-1}+\Pi_{2} Y_{t-2}+\cdots+\Pi_{p} Y_{t-p}+\varepsilon_{t}
$$

Where $Y_{t}$ : A vector ( $\left.n \times 1\right)$ from autoregression of $p$ order; $\alpha$ : Represents an intercept $\operatorname{vector}(n \times 1) ; \Pi_{i}$ : Are parameter matrices of order $(n \times n)$; and $\varepsilon_{t}$ : is the error term $\varepsilon_{t} \sim \operatorname{iidN}\left(0, \sum\right)$.

In determining the VAR model that best fits, there is the impact of innovations through the Impulse Response Function and the Variance Decomposition.

Block et al. (2012) consider that the VAR model allows obtaining the elasticity impulse for $k$ periods ahead, where the impulse of elasticity enables to evaluate the behavior of the variables in response to individual shocks at each level of the econometric model. And the Decomposition of Variance provides an estimate of how much the variance of a variable is related to variations in itself and in relation to other variables from the model (Ribeiro et al., 2006).

\section{RESULTS AND DISCUSSION}

From the proposed methodology, the table below shows the results obtained in research on price elasticity of transmission of chicken in São Paulo state market in the producer level, wholesale and retail.

\subsection{Unit root test}

The augmented Dickey-Fuller (ADF) test for unit root was performed with the variables at level and with the first difference to verify if the elasticity transmission price model for chicken has stationary characteristics.

Thus, it was found that the time series of prices are not stationary. However, after being logarithmyzed by the first difference they become stationary. The unit root test was estimated for the monthly time series with constant and with constant and trend, both at level as in their differences, as shown in Table 1.

Table 1. Unit Root Test of the ADF series ( $p$-value calculated $\tau$ ).

\begin{tabular}{llcc}
\hline \multicolumn{1}{c}{ Categories } & \multicolumn{1}{c}{ Variable } & With constant & $\begin{array}{c}\text { With constant } \\
\text { e tendency }\end{array}$ \\
\hline \multirow{3}{*}{ Series em level } & APP Producer & 0,8785 & 0,4656 \\
& APC Wholesale & 0,8935 & 0,0000 \\
& APC Retail & 0,8803 & 0,1810 \\
\hline \multirow{3}{*}{ Series in diferences } & Id APP Producer & 0,0000 & 0,0000 \\
& Id APC Wholesale & 0,0000 & 0,0000 \\
& Id APC Retail & 0,0000 & 0,0000 \\
\hline
\end{tabular}


The ADF unit root test with constant and with constant and trend show that price series are integrated of order 1,1 (1), and do not have a unit root, which allows the application of Johansen's cointegration test.

\subsection{Cointegration test analysis Johansen}

The number of lags was estimated by the delay selection model of Vectors Autoregressive (VAR). Regarding the number of lags, it was decided to use the Akaike Information Criteria (AIC), Bayesian Schwarz (BIC) and Hannan-Quinn (HQC) following the guidance of Margarido, Turolla and Fernandes (2001).

In choosing the most appropriate information criterion 0 (zero) to 12 (twelve) lags was used. And, as the results in Table 2 show, the Bayesian Information Criterion of Schwarz was the most adjusted to the model, suggesting only a lag.

Table 2. Results of the lag order criterion.

\begin{tabular}{cccc}
\hline Lag & AIC & BIC & HQC \\
\hline 1 & $-7,352868$ & $-7,131517^{*}$ & $-7,263046$ \\
2 & $-7,423074$ & $-7,035711$ & $-7,265887^{*}$ \\
3 & $-7,488738^{*}$ & $-6,935362$ & $-7,264184$ \\
\hline
\end{tabular}

Legend: * Indicates the best values, i.e. the minimum of delay selected by criteria.

After determining the number of lags Johansen's cointegration test was performed. It was found that the model presents three cointegrating vectors between the three variables of prices. And the null hypothesis of the existence of three cointegration vectors was rejected at $1 \%$ significance in this model, according to data from the constant $p$-value in Table 3, suggesting the existence of three cointegration relations.

Table 3. Results of the Johansen test for cointegration.

\begin{tabular}{cccc}
\hline No of cointegration vectors & Auto value & Trace test & P-value \\
\hline 0 & 0,73411 & 478,76 & $0,0000^{*}$ \\
1 & 0,55221 & 239,00 & $0,0000^{*}$ \\
2 & 0,40370 & 93,579 & $0,0000^{*}$ \\
\hline
\end{tabular}

Legend: * Significance level $1 \%$.

When the time series are cointegrated Mayorga et al. (2007) recommend working with series the level to avoid spurious regressions. And, following the guidance of this author this research works with the series level, since there are three cointegration relationships in the evaluated model.

The Vector Autoregressive model (VAR) at level is used because the number of cointegration vectors is equal to the number of variables. Thus, by placing the variables in level, the combination of them produces a stationary relationship.

\subsection{Variance decomposition}

After the econometric treatment, the results of the variance decomposition of forecast errors of variables I APP Producer, I APC Wholesale and I APC Retail are shown in Table 4. 
In order to standardize the variance, from the model were transformed in logarithm. Thus, the first column consists of the variables that have been assigned to an unanticipated shock, the second column represents the size of the analyzed periods which are expressed in months, and between the third and fifth columns the proportions of prediction errors are shown for each variable of the model.

Table 4. Results of the variance decomposition of forecast errors in percentage.

\begin{tabular}{ccccc}
\hline Variables & Period & I APP Producer & I APC Wholesale & I APC Retail \\
\hline 1 & 100,0000 & 0,0000 & 0,0000 \\
I APP Producer & 2 & 99,0999 & 0,0275 & 0,8725 \\
& 3 & 98,2396 & 0,2151 & 1,5453 \\
& 4 & 97,4063 & 0,5592 & 2,0345 \\
& 6 & 95,8024 & 1,4836 & 2,7140 \\
& 8 & 94,3772 & 2,4458 & 3,1770 \\
I APC Wholesale & 10 & 93,1872 & 3,2989 & 3,5139 \\
& 12 & 92,2222 & 4,0101 & 3,7676 \\
\hline 1 & 39,3739 & 60,6261 & 0,0000 \\
& 2 & 47,2099 & 50,1525 & 2,6376 \\
& 3 & 52,4884 & 43,3101 & 4,2015 \\
& 4 & 56,3920 & 38,5862 & 5,0218 \\
& 6 & 61,7544 & 32,5032 & 5,7424 \\
& 8 & 65,1702 & 28,8099 & 6,0199 \\
& 10 & 67,4643 & 26,3862 & 6,1495 \\
& 12 & 69,0716 & 24,7088 & 6,2196 \\
\hline 1 & 35,4136 & 35,6679 & 28,9185 \\
& 1 & 42,3196 & 36,7729 & 20,9075 \\
& 2 & 47,7646 & 35,0912 & 17,1442 \\
& 3 & 52,0961 & 32,8984 & 15,0055 \\
& 4 & 58,3104 & 29,0298 & 12,6598 \\
& 6 & 62,3590 & 26,2427 & 11,3983 \\
& 8 & 65,0956 & 24,2864 & 10,6181 \\
& 10 & 67,0150 & 22,8899 & 10,0951 \\
\hline & 12 & & &
\end{tabular}

According to the results, when the unanticipated shock in the variable average price of live poultry paid to the producer ( $A P P$ Producer), changes in chicken prices are explained by the same variable, at first. It is observed that the variance of forecast errors remains high after 12 months after the unanticipated shock, with about $92.22 \%$, without significant influence of the wholesale and retail in the composition of producer prices.

When the unanticipated shock in the variable average price of chicken slaughtered for wholesale (I APC Wholesale), about $60.62 \%$ of the variation in prices is explained by the own variable, at first, and over the course of months the power price formation is transferred to the variable I APP Producer. Thus, the average price of slaughtered chicken for wholesale is influenced by the price paid to producers in about $69.07 \%$ after 12 months of unanticipated shock. 
Regarding the unanticipated shock occurred in the variable average price of chicken in retail (I APC Retail), by the variance of forecast errors it is verified that at first, about $28.91 \%$ of price formation is explained by the variable itself. After 12 months of unanticipated shock, both the variable I APP Producer as the variable I APC Wholesale have influence on the power of price formation practiced in retail, with $67.01 \%$ and $22.88 \%$, respectively.

\subsection{The impulse response function results}

The combined graphics of the elasticity impulse response function in Figure 2 show the direction and the average price behavior of chicken in the state of São Paulo market over the analyzed period. Between the first and the third column the charts depict the answers or returns of the variables regarding the effects of unanticipated shocks in I APP Producer, I APC Wholesale and I APC Retail, respectively.

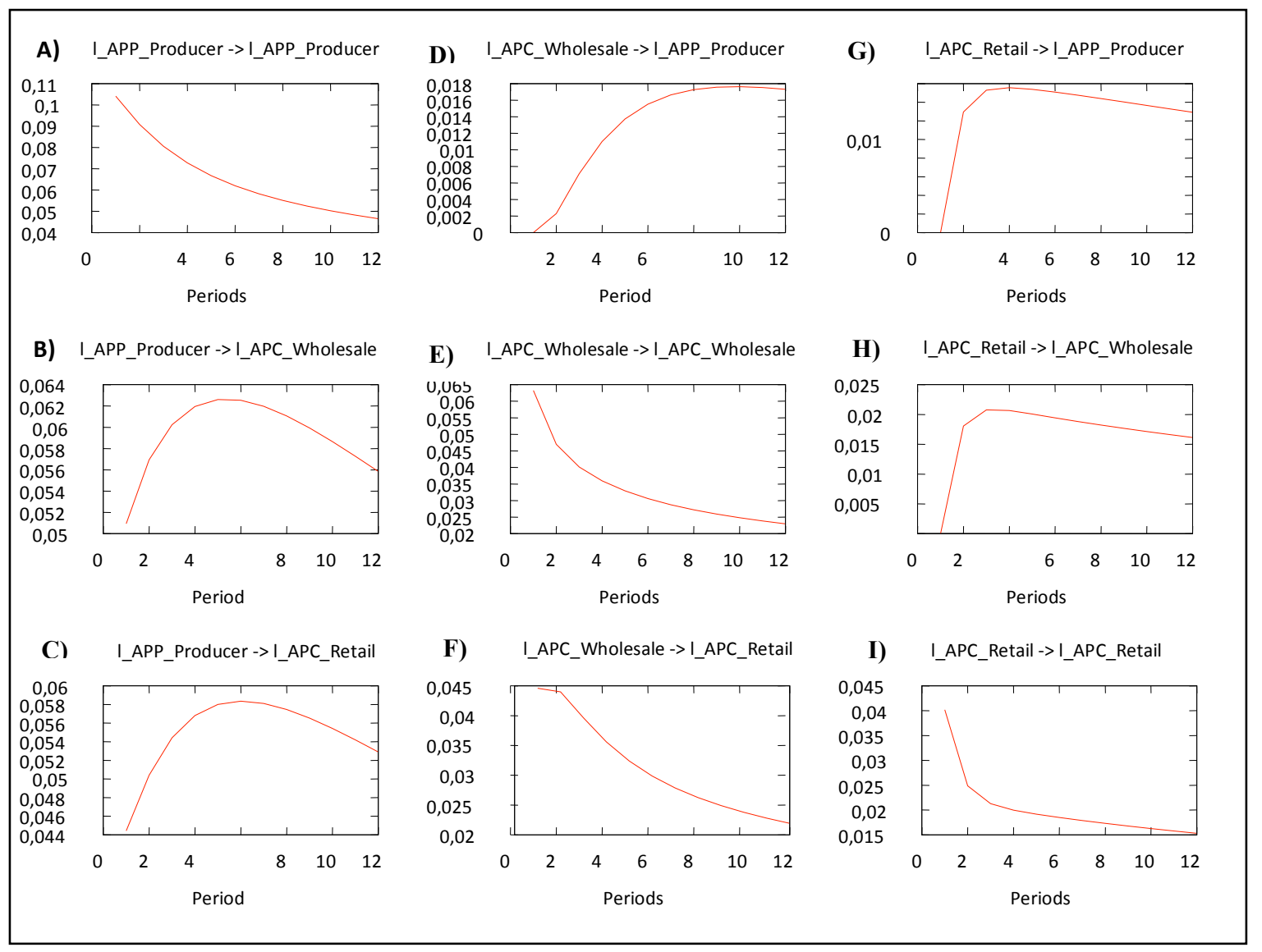

Figure 2. Impulse response functions.

The Graphics ( $A, B$ and $C$ ) shown in the first column indicate the effects of the price shock of variable I APP Producer on variables I APP Producer, I APC Wholesale and I APC Retail.

The results show that because of the shock on the variable I APP Producer, implies a decrease of price curve in the variable itself (Graphic A) between the first and twelfth month. Regarding the impact of the variable I APP Producer causes an increase in price curve in the variable I APC Wholesale (Graphic B) between the first and sixth month and prices decay in the 
following months. The behavior of price curve of the variable I APC Retail (Graphic C) shows similar behavior, up until the sixth month, and decays in the following months.

It is observed that when there are increases in the price of the variable I APP Producer, the degree of response is fast on variables I APC Wholesale and I APC Retail, with price increases to reach its maximum in the first six months.

The Graphics (D, E and $F$ ) shown in the second column indicate the effects of the price shock of variable I APC Wholesale on variables I APP Producer, I APC Wholesale and I APC Retail.

To the shock in the variable I APC Wholesale, plays an exponential rise in price curve of the variable I APP Producer (Graphic D) of the first to the twelfth month. Different result occurs in price curve of the itself variable (Graphic E) and in the variable I APC Retail (Graphic F) declining sharply between the first and twelfth month.

It appears that, with the rising prices of variable I APC Wholesale, both the price curves of the variables I APC Wholesale and I APC Retail decays exponentially, and initially, an increase in the prices of variable I APC Wholesale causes immediate increase in prices the variable I APP Producer.

The Graphics (G, H and I) of the third column indicates the shock effects in the variable I APC Retail on variables I APP Producer, I APC Wholesale and I APC Retail.

Initially, the results reveal that a shock in the prices of variable I APC Retail implies an increase in the price curve of variable I APP Producer (Graphic G) until the fourth month, obtaining a smooth decreasing rate until the twelfth month. The behavior of the price curve of variable I APC Wholesale (Graphic H) shows similar behavior to increase until the fourth month, and decreasing rate until the twelfth month. On the other hand, the price curve of variable I APC Retail (Graphic I) undergoes sharp fall from the first month to the twelfth month.

Thus, an increase in the prices of variable I APC Retail causes increase in the price curve of the variables I APP Producer and I APC Wholesale rapidly, reaching its maximum until the fourth month.

\section{CONCLUSIONS}

By analyzing the elasticity of price transmission from chicken in the state of São Paulo market this research sought to identify which market level is the former agent of chicken prices, whether at the producer level, wholesale or retail. Therefore, we used an econometric model based on the Vectors Autoregressive methodology.

The results found by analyzing the variance decomposition of forecast errors showed that the producer has a high power setting of prices of chicken in the domestic market of Sao Paulo, with direct influence on the formation of prices in both levels wholesale and retail. And, the prices at retail have influence next $23.0 \%$ in wholesale. Since retail prices have little significant influence on the prices charged by the producer and wholesale. The results of the impulse response function ratify those found on the decomposition of the variance.

As the market level of the producer of chicken meat has a strong influence on price formation, both at the wholesale and retail level, some measures taken by public officials and poultry chain managers can contribute to the balance in the price transmission between different 
market levels and the development of sector. Thus, it is necessary to have public policies that aim to stabilize the supply of chicken meat and price controls in this market in order to reduce uncertainties and risks present in the activity, as well as make it more attractive to the poultry activity to producers.

The price variations over the period studied, shown in Figure 1 may have been caused by climatic factors along with economic factors, that somehow influenced the pricing of chicken between the three markets levels analyzed. As the producer is forming prices, one can infer that their prices are tied to the prices of inputs used in the production of chicken, either with food or technology used, since the production of inputs that make up feeding the birds has dependence on biological and climatic conditions influencing the product offering in the market, that is, if there is excess or shortage and may thus cause a decline or increase in the prices of chicken.

\section{REFERENCES}

Adkins, L. C. (2012). Using gretl for principles of econometrics. Received on February 19, 2016 of http://gretl.sourceforge.net/win32/index_pt.html

Akaike, H. (1976). Canonical correlations analysis of time series and the use of an information criterion. In: Advances and Case Studies in System Identification. New York: Academic Press, 27-96.

Applied Economic Research Institute-IPEA. Household income per capita average. Received on February 19, 2016 of www.ipeadata.gov.br

Arêdes, A.; Silveira, S. F. R.; Lima, A. A. T. F. C.; Arêdes, A. F.; Pires, S. V. (2006). Análise de custos na pecuária leiteira: um estudo de caso das propriedades assistidas pelo Programa de Desenvolvimento da Pecuária Leiteira da Região de Viçosa. Custos e Agronegócio On Line, Recife, 2(1), 45-48.

Barros, G. S. A. C. (1990). Transmissão de preços pela central de abastecimento de São Paulo, Brasil. Revista Brasileira de Economia, Rio de Janeiro, 44(1), p.5-20.

Batalha, M. O. (2012). Gestão agroindustrial. 3. ed. São Paulo: Atlas.

Belke, A.; Orth, W.; Setzer, R. (2010). Liquidity and the dynamic pattern of asset price adjustment: A global view. Journal of Banking and Finance, 34(8), 1933-1945.

Block, A.; Block, D. A.; Veloso, G. O. (2012). Análise da transmissão de preços no setor sucroalcooleiro brasileiro. Revista Eletrônica de Estratégia e Negócios, Florianópolis, 5(2), 120-137.

Brazilian Poultry Union-UBA. Consumption per capita. Received on February 19, 2016 of www.ubabef.com.br

Bryman, A. (2007). Barriers to integrating quantitative and qualitative research. Journal of Mixed Methods Research, 1(1), 8-22. 
Bryman, A. (2006). Integrating quantitative and qualitative research: how is it done? Qualitative Research, 6(1), 97-113.

Bryman, A.; Becker, S.; Sempik, J. (2008). Quality criteria for quantitative, qualitative and mixed methods research: a view from social policy. International Journal of Social Research Methodology, 11(4), 261-276.

Cavalcanti, M. A. F. H. (2010). Identificação de modelos var e causalidade de Granger: uma nota de advertência. Economia Aplicada, 14(2), 251-260.

Creswell, J. W. Designing a qualitative study. In: Creswell, J. W. 2013. Qualitative inquiry and research design. London: Sage, 42-68.

Dickey, D. A.; Fuller, W. A. (1979). Distribution of the estimators for autoregressive time Series with a unit root. Journal of the American Statistical Association, 74(366), 427-431.

Fernandes, R. A. S.; Braga, M. J.; Lima, J. E. (2010). Elasticidade de transmissão e formação espacial de preços de leite ao produtor nos maiores estados produtores. Revista de Economia e Administração, 9(3), 368-385.

Figueiredo, A. M.; Souza Filho, H. M.; Guanzirolli, C. E. Valente Junior, A. S. (2010). Análise da transmissão de preços no mercado brasileiro de castanha de caju. Documentos TécnicoCientíficos, Brasília, 41(4), 715-730.

Gaio, L. E. Castro Junior, L. G.; Oliveira, A. R. (2006). Causalidade e elasticidade na transmissão de preço do boi gordo entre regiões do Brasil e a bolsa de mercadorias \& futuros (BM\&F). Organizações Rurais \& Agroindustriais, Lavras, 7(3), 282-297.

Hannan, E. J.; Quinn, B. G. (1979). The determination of the order of an autoregression. Journal of the Royal Statistical Society Series B-Methodological, 41(2), 190-195.

Hassouneh, I.; Radwan, A.; Serra, T.; Gil, J. M. (2012). Food scare crises and developing countries: The impact of avian influenza on vertical price transmission in the Egyptian poultry sector. Food Policy, 37, 264-274.

Hassouneh, I.; Serra, T.; Gil, J. M. (2010). Price transmission in the Spanish bovine sector: the BSE effect. Agricultural Economics, 41, 33-42.

Johansen, S.; Juselius, K. (1990). Maximum likelihood estimation and inference on cointegration with applications to the demand for money. Oxford Bulletin of Economics and Statistics, 52(2), 169-210.

Johansen, S. (1988). Statistical analysis of cointegration vectors. Economics Dynamics and Control, 12, 231-254.

Lobo, O. A.; Neto, W. A. S. (2011). Transmissão de preços entre o produtor e varejo: evidências 
empíricas para o setor de carne bovina em Goiás. Conjuntura Econômica Goiana, Goiânia, 19(1), 57-63.

Lunde, A.; Heggen, K.; Strand, R. (2012). Knowledge and Power: exploring unproductive interplay between quantitative and qualitative researchers. Journal of Mixed Methods Research, 7(2), 197-210.

Margarido, M. A.; Turolla, F. A.; Fernandes, J. M. (2001). Análise da elasticidade de transmissão de preços no mercado internacional de soja. Pesquisa \& Debate, São Paulo, 12(2), 5-40.

Mayorga, R. O. Khan, A. S.; Mayorga, R. D.; Lima, P. V. P. S.; Margarido, M. A. (2007). Análise de transmissão de preços do mercado atacadista de melão do Brasil. RER, Rio de Janeiro, 45(3), 675-704.

Paulista Poultry Association-APA. Statistic. Received on February 19, 2016 of www.apa.com.br

Ribeiro, K. C. S.; Sousa, A. F.; Rogers, P. (2006). Preços do café no Brasil: variáveis preditivas no mercado à vista e futuro. Revista de Gestão USP, São Paulo, 13(1), 11-30.

Silva, E. L.; Menezes, E. M. (2005). Metodologia da pesquisa e elaboração de dissertação. 4. ed. Florianópolis: UFSC.

Schwarz, G. (1978). Estimating the dimension of a model. Annals of Statistics, 6, 461-464.

Sims, C. A. (1980). Macroeconomics and reality. Econometrica, 48(1), 1-48.

Viana, J. G. A.; Zen, B.; Karlec, F.; Souza, R. S. (2010). Comportamento dos preços históricos do leite no Rio Grande do Sul, Brasil. Ciência e Agrotecnologia, Lavras, 34(2), 451-460.

Weydmann, C. L.; Seabra, F. (2006). Transmissão de preços na cadeia de carne suína: uma aplicação para os preços de São Paulo. Revista de Economia e Agronegócio, 4(3), 269-288.

Wooldrige, J. M. (2009). Introductory Econometrics: a modern approach. 4th. Cengage Learning. 